\title{
The Multiple Dialectics of a Text and Author-A Study on Seng Zhao's Non-Complete Emptiness (Bu zhenkong lun)
}

\author{
Kai Shmushko
}

Citation: Shmushko, Kai. 2021. The Multiple Dialectics of a Text and Author-A Study on Seng Zhao's Non-Complete Emptiness (Bu zhenkong lun). Religions 12: 462. https:// doi.org/10.3390/rel12070462

Academic Editor: Vesna Wallace

Received: 22 April 2021

Accepted: 21 June 2021

Published: 24 June 2021

Publisher's Note: MDPI stays neutral with regard to jurisdictional claims in published maps and institutional affiliations.

Copyright: (C) 2021 by the author. Licensee MDPI, Basel, Switzerland. This article is an open access article distributed under the terms and conditions of the Creative Commons Attribution (CC BY) license (https:// creativecommons.org/licenses/by/ $4.0 /)$.
School of Historical Studies, Tel Aviv University, P.O. Box 39040, Tel Aviv 6997801, Israel; kaishmushko@mail.tau.ac.il

\begin{abstract}
In discussing the arrival of Buddhism to China, Erik Zürcher describes the meeting of "a jungle of Buddhist metaphysics" with other local philosophies and practices. This period was a transformative encounter with wide-ranging ramifications, including for textual traditions. Noncomplete Emptiness (Bu zhenkong lun 不真空論), written by Seng Zhao 僧肇, is one product of this encounter. While explaining the principle of emptiness, Non-complete Emptiness incorporates Daoist and Confucian terminologies and elements. Nevertheless, the text is considered formative for the development of Buddhist writing and practice during the critical period of Buddhism's assimilation into China in the third to fifth centuries AD. This study of Non-complete Emptiness looks at the philosophical and cultural relevance of the text. It suggests a methodological solution to some of the tensions that have arisen from Seng Zhao's notion of emptiness. The article begins by looking into the historical and hermeneutical tendencies in the scholarship of Non-complete Emptiness. The following section provides a textual and cultural analysis of the text and its author, viewing the sage as an "open entity", to understand Seng Zhao's idea of emptiness. This analysis suggests that a multiple dialectic approach should be followed to improve the understanding of the text's Buddhist message and Seng Zhao's position as a scholar-monk in medieval China.
\end{abstract}

Keywords: Buddhism; hermeneutics; Daoism; Chinese philosophy; Madhyamaka; emptiness; Confucianism

\section{Introduction}

The complexity of the essay Non-complete Emptiness and its inclusion of subtle messages from the eminent monk and esteemed writer Seng Zhao 僧肇 have resulted in this text lacking popularity among Western scholars. ${ }^{1}$ Nevertheless, some important works have been written about the essay in previous decades. These have tried to interpret Seng Zhao's arguments and contextualize them within Madhyamaka philosophy and Chinese philosophical traditions. The textual acquisitions and Sinological studies conducted on this essay, while scarce among Western scholars, are nevertheless comprehensive. ${ }^{2}$ Seng Zhao was a Buddhist scholar-monk who lived in the eastern Jin dynasty (378 to 413) and played a role in Kumārajīva's translation team. The comprehensive work of Kumārajīva and his team held great importance at that time and throughout history. ${ }^{3}$ Seng Zhao was a member of this translation team and one of Kumārajīva's main disciples. He was born to a poor family and began his career as a book copier, which allowed him to become thoroughly familiar with a great range of classic Confucian and early Daoist works. His literary background proceeding his entry into Buddhism is evident in his work and consequently influenced the development of Chinese Buddhism. The assemblage of Buddhist philosophy with Daoist and Confucian ideas is a prominent subject of studies about Seng Zhao's writings (Dippmann 1997, p. 33). ${ }^{4}$

Non-complete Emptiness can be read as a stand-alone essay that provides a means of interpretating "emptiness" (Sk. Śn̄nyatā Ch. kong 空). ${ }^{5}$ However, among some scholars, it is accepted that the text belongs to a four-part compilation with a soteriologically oriented 
order named The Treatise of Seng Zhao (Zhaolun 肇論). This order, according to Jeffrey Dippman, is part of a larger endeavor through which Seng Zhao expounded his Middle Way (Dippmann 1997, pp. 14-15). ${ }^{6}$ There is an inner logic that connects the different essays together in order to articulate a base for attaining enlightenment. Non-complete Emptiness is the second stage in this process. The first stage describes the understanding of all things as being devoid of an intrinsic self and therefore "empty". Thereafter comes Non-complete Emptiness as the second stage, in which, generally, "emptiness" is explained as being non-absolute, despite the fact that it is the best form to describe the nature of reality. The next (third) essay is about Prajñ $\bar{a}$, which is a specific wisdom or insight that provides a way to understand emptiness. The last essay concerns Nirvanna, which completes the enlightenment process that the four essays represent as a whole. The texts were kept and passed forward in the order noted here and not in their chronological order; this choice was made to fulfill a soteriological aim. The reason the essays appear in this order today is due to medieval China's religious philosophical sphere, which aimed to fulfill the goals of Indian Madhyamaka. The editors were loyal to the aim derived from the socio-religious sphere, which was to continue Nagarjuna's path. Jeffrey Dippmann argues that this order not only philosophically explains the subtle meaning of emptiness according to Madhyamaka's way of thinking, but also directs the reader towards enlightenment (Dippmann 1997, pp. 18-20).

I agree with the holistic approach, which assembles the different subjects of the essays to form a particular practical approach suggested by Seng Zhao. However, I do see a cavity in considering only a soteriological understanding of The Treatise of Seng Zhao, because it is based on an emic prospective. I hold that beyond the general acceptance of the order and the soteriological aim, reading the essays strictly as a Buddhist cultivation path might leave out some details that are important for understanding Seng Zhao's message. Therefore, adding to this approach, I propose that every part of the Treatise of Seng Zhao should be carefully read and situated. I hold that, written as a complete essay, Non-complete Emptiness also employs a distinct approach of its own. My methodological approach is to step out of the holistic approach and investigate the inconsistencies of the text. Through this process, I go back to questions that float within and around the essay: is the text purely Buddhist? Where does it align with Daoist or Confucian traditions? I also add questions that reconnect the message of the text with its author. For example, does Seng Zhao's Emptiness represent a purely ascetic point of view? I do not wish to give a clear-cut answer to these questions, but rather to use them as a hermeneutical tool for understanding the text and its author.

\section{Dialectic Thinking beyond Language and Culture}

Various scholars have attempted to understand whether Seng Zhao did or did not truly understand Buddhism (Ichimura 1992, p. 51). I hold that the first element of the essay that encourages this endeavor is the eclecticism that characterizes Seng Zhao and his writing. Seng Zhao creates an assemblage of elements from different thought traditions, which, for some scholars, raises a question about his correct understanding of Buddhist thought. Another obvious reason is the identity of the composer-a Chinese monk who wrote about Buddhist doctrines in a very early stage of its development in China. At this point, different terms which are today broadly accepted as translations or transliterations of the Sanskrit terms were not yet concretely set. For these reasons, I suggest that the question to be asked is how Seng Zhao understood Buddhism-namely, what are the unique characteristics of his understanding of Emptiness in Non-complete Emptiness? Before suggesting my approach of multiple dialectics, I discuss the eclectic nature of the essay.

According to Shohei Ichimura, the fifth-century Chinese understanding of Buddhist terms was very advanced and the grasp of the term Emptiness at the time was correspondingly accurate. He suggests that the reason for this was the transcultural nature of the dialectic method of Madhyamaka, and The Treatise of Seng Zhao is evidence of this (Ichimura 1992, p. 51). He criticizes Liebenthal for arguing that Seng Zhao and his writings bring about a misunderstanding regarding Indian Buddhism. Walter Liebenthal argued 
that when it comes to understanding Nagarjuna's relationship between the two spheres, Seng Zhao distinguishes too strongly between truth and illusion (Liebenthal 1968, p. 27). He was referring here to the doctrine of two truths, which holds that there are two levels of truth: the conventional truth (Sk. samvrtisatya, Ch. shisudi 世俗諦) and the ultimate or absolute truth (Sk. paramārtha satya Ch. chenyidi 勝義諦). As I explore in the second part of this article, Non-complete Emptiness can be understood through very delicate and complex dialectics, which also account for the apparent dichotomy between the two distinguished spheres of truth. Therefore, understanding the seemingly negative aspects of Seng Zhao's philosophy as dialectics is crucial for acknowledging his understanding of Madhyamaka philosophy.

Regarding this dispute, Robinson stands alongside Ichimura and advocates for a very clear Madhyamaka understanding through The Treatise of Seng Zhao (Robinson 1976, pp. 148-58). This kind of dialectic thinking, which was developed by Nagarjuna, shares commonalities with the developmental processing of the mind. Hence, dialectic thinking and logical mental processes are thought to derive from modifications of the same basic structure of the mind. Thus, the basis of the ancient Indian logic system is similar to that of the ancient Mohists. ${ }^{7}$ While these systems are merely similar and not identical, they are important because they both portray a rule for logic that is supposed to apply to any circumstances or conditions. Ichimura shows that the actions of the human mind share a common base that is beyond culture, language, and tradition. This allowed Seng Zhao to understand the Madhyamaka method of logic (Ichimura 1992, p. 54). Furthermore, in contrast to cultural distribution, paradoxically, religiosity or transcendental adherence entail the usage of individuality. In this way, one can cut through one's own linguistic and cultural forms and step out beyond one's own cultural and linguistic media. The Chinese understanding of Madhyamaka can, therefore, be used as a case study to show that mental understanding - consciousness transformation that one goes through in grasping Emptiness-is personal. It is inherent and not influenced by one's language, culture, or traditional identity (Ichimura 1992, p. 67).

I resonate with Ichimura's approach for pointing at dialectic thinking, as an element that can share common ground with other thought traditions. This approach is presented in Seng Zhao's discussion on language; Non-complete Emptiness describes the spiritual path to Emptiness (Ch. kong 空) as a path that can be practiced beyond the scope of language (Dippmann 1997, pp. 468-69). The issue of the insufficiency of language is also central in Laozhuang literature, which focuses on expounding the Dao (道) ${ }^{8}$-for example, Zhuangzi's use of the net as a metaphor for language: a fishing net, once it is used, can be cast aside (Zhuangzi 2000, p. 187, 11. 7-10). The net is merely a tool-a tool of no great importance, at that. Words can be used and then replaced. They are not the object itself. Influenced by the Daoist approach to language, Seng Zhao uses language reluctantly (Dippmann 1997, pp. 467-68).

"Therefore, the sphere of truth is beyond the noise of verbal teaching. How then can it be made a subject of discussion? (I) Still cannot remain silent. In spite (of that which I have said), I will state my opinion and defend it." (Taisho Shinshu Daizokyo 1922-1933, 1858, 45:152a, 11. 1-3)

I suggest that Seng Zhao acknowledged the problem with the Madhyamaka-style logical explanation of the use of language. Therefore, he also described Emptiness through the figure of a sage and his experience in the world which I discuss in the second part of this paper. In agreement with Ichimura, I see the sage's experience as the crossing of personal borders-the borders of the self. These are, specifically, language, habits, and cultural norms.

Galia Patt-Shamir asserts the significance of one's geographical location and its influence on how one perceives and understands different ideas, especially ideas that are outside one's own traditional sphere. In her reading of Non-complete Emptiness, she cites the conception of God from Christian, Muslim, and Jewish perspectives as an example. While all three religions have a concept of God, the meaning of the religion to practitioners 
is different in each case. She uses this example to describe the Chinese understanding of Indian concepts. Both traditions recognize the concept of Emptiness, but in different manners. The Indian understanding is characterized by an apophatic negative way of describing reality, while the Chinese orientation is a more cataphatic positive approach that engages with reality. Accordingly, Non-complete Emptiness can be understood from both Indian and Chinese points of view. Seng Zhao's Emptiness holds a "dual citizenship", incorporating both Buddhist and Daoist interpretations (Patt-Shamir 2011, vol. 38, p. 475).

Concluding this discussion, I would add that both the Dao and the Dharma are flexible and inclusive. ${ }^{9}$ The Buddhist tradition inherently accepts the use of different techniques and skills in order to spread the Dharma to others. This is expounded through the doctrine of Skillful Means (sk. Upāya ch. fangbian 方便), which holds that various methods and technologies can be used to ease the suffering of people and help them progress along the road to liberation. Similarly, the Dao, as a formative philosophical concept in China, encourages diverse expressions through different streams of thought, teachers, and religious groups. The flexibility of Upāya and the versatility of Dao drive Patt-Shamir's argument for two different "citizenships" for Seng Zhao's Emptiness (Patt-Shamir 2011, p. 475). As I explore later on, these two citizenships may be compiled from many more "citizenships" situated between Buddhism and Daoism. ${ }^{10}$

\section{Ge-Yi and Buddhist Hermeneutics}

By using the Laozi, Zhuangzi, Guo Xiang's commentary on the Zhuangzi, and other Chinese classics, Seng Zhao set up his own version of Madhyamaka philosophy. Seng Zhao's time of life (the first hundred years BC) was important for the development of his linguistic strategy and writing. Seng Zhao was vastly influential in this development, to the extent that he played an important role in the emergence of later Buddhist schools in the Sui dynasty, such as Tiantai (天台) and Sanlun (三論) schools (Kantor 2010, vol. 20, p. 284) However, he is not the inventor of this exegetical method, which borrows scriptures from the Chinese-particularly Daoist—in order to expound Buddhist doctrines, but was most likely influenced by it (Chen 2004, p. 63).

The term Ge-yi (格義) literally means "matching meanings" or "matching concepts". It is an important term which is used in studies of the assimilation of Buddhism in China and translation comparisons. The meaning of the term can be divided into two main uses. Contemporary scholars of Buddhism from Asia use the term with reference to a system of translating terms or ideas (Kantor 2010, p. 285). However, this term also represents an earlier stage in the historical development of Buddhism in China during the Three Kingdoms period and the succeeding Jin dynasty (Kantor 2010, p. 284). ${ }^{11}$

However, despite the influence of the Ge-yi system on the writing of Seng Zhao, it does not account for his particular understanding of Madhyamaka. Victor Mair pointed out the great difficulty in attributing a translation to a certain intellectual-religious school or orientation. For example, Nirvāna is translated into wuwei (無为) in some Buddhist scripture translations.

"Even wuwei, which geyi enthusiasts constantly invoke as one of their favorite examples of an early Buddhist borrowing of 'Daoist' terminology, was certainly not restricted to Daoist texts, but was used more broadly by Confucians and others." (Mair and Sen 2012, vol. 48, p. 54).

What can be understood from Mair's conclusions about Ge-yi is that simply trying to understand Seng Zhao through Daoist thought might provide a limited view. Therefore, Geyi might also never give an answer as to whether or not the Chinese understood Buddhism in the same way that the Indians did. To conclude this part of the article, the question of whether the Chinese understood Buddhism is an important one, because it reveals the way in which the studies of Chinese Madhyamaka and Buddhism as a whole have been viewed. However, I propose that the answer to this question is not as important as the process of inquiry into the background that this question arises from (a philosophically 
and religiously diverse period in Chinese history). By trying to measure and quantify the degree of understanding, scholars attribute an "inner and outer" dichotomy to a tradition of thought and religious practice. In this inquiry, there is an underlining assumption that Buddhism came from the outside and entered China geographically, sociologically, and spiritually. If we try to view religion and its texts through a less linear approach and more as an entangled interaction of beings, practices, and symbols, a "yes or no" answer to this question might prove to be less relevant.

\section{Multiple Dialectics}

In discussing the arrival of Buddhism to China, Zürcher describes "a jungle of Buddhist Metaphysics" which met other local philosophies and practices (Zürcher 1972, p. 73). This was a transformative encounter with wide-ranging ramifications, including for textual traditions. Non-complete Emptiness is one product of this. As discussed in the first two parts of this article, scholars have attempted to situate the work within a particular tradition, such as Indian Madhyamaka, Laozhuang literature, or Neo-Daoism (xuanxue 玄學). In the process, various questions have arisen: is Non-complete Emptiness a work of pure Indian Madhyamaka thought? Alternatively, is this the first Chinese Madhyamaka (sanlunzong 三論宗) text? Should it, instead, be characterized as hybrid Buddhism? (Dippmann 1997, pp. 3-5). I adopt Zürcher's image of a "jungle" as a general framework for the present paper, while I try to decipher Seng Zhao's philosophy in both metaphysical and practical ways. To this end, I use several dialectics discovered in my reading to navigate this highly complex work. These attend to both Daoist and Buddhist attributes of the essay. I suggest that there is a sensory dimension to the entity that Seng Zhao describes, which generates what I refer to as an "open entity". ${ }^{12}$ Furthermore, I discuss how the construction of this entity reflects Seng Zhao's approach to asceticism, his relationship with Laozhuang literature, which I started to discuss in previous sections, and his identity as a scholar-monk.

\subsection{Transcendental-Earthly}

Modern research on The Tretise of Seng Zhao considers mysticism to be a significant prism. Walter Liebenthal and Richard Robinson, for example, both argue for a strong mystical aspect in The Tretise of Seng Zhao. ${ }^{13}$ This is true despite Robinson's view that the doctrinal thrust of mysticism prevents it from contributing significantly to our understanding of the described experience in the essays (Robinson 1958, p. 102). While I agree that Seng Zhao's description of Emptiness can be characterized as mystical, in my view, this is mainly due to the flexibility of the term. ${ }^{14}$ In addition to generating a broad range of meanings, its significance is obviated by the clear eclecticism of this work. Setting aside this eclecticism, I have identified some particular gaps within it that I wish to attend. I am not referring to the fact that the text contains a mixture of references to Prajñāpāramitā sutras, Laozhuang literature and to Nāgārjuna's Mūlamadhyamakakārikā (hereafter MMK. Patt-Shamir 2011, p. 475). ${ }^{15} \mathrm{I}$ am also not referring to the multiple genres contained in the text-namely, narrative writing, "chain argumentation", and so forth (Liebenthal 1968; Waley 1958, p. 175). Instead, I argue that the message Seng Zhao conveys through his mystical and eclectic description of Emptiness allows for a range of interpretations regarding entities, substances, practices, and the relations between them. Non-complete Emptiness opens with a description of Emptiness:

"A perfect void where nothing grows (and decays) such is, perchance, the transcendental realm as it shows in the dark mirror of Prajña into it all that exists and does not exist is dissolved ... " (Taisho Shinshu Daizokyo 1922-1933, 1858, 45:152a, 1. 2).

Emptiness is, thus, a void ( $x u$ 虚), an unworldly, transcendental sphere that is reached through Prajñā (banruo 般若). Prajñā, here, is a key, an acuity to this realm. When one has this acuity, he ontologically enables this other realm to exist (Patt-Shamir 2011, p. 476). Hence, ontological existence or not depends upon whether one obtains Prajñā or not. Emptiness is outside the borders of our mundane reality; it is not part of the world 
(Liebenthal 1968, p. 54). In relation to this description of Emptiness, an experience of an entity-a sage-is described.

"(only) the perfect being may let his mind go beyond the borders of finality, unrestricted by these borders, may send his eyes and ears beyond the limits of seeing and hearing [to regions] where eyes and ears cannot reach." (Taisho Shinshu Daizokyo 1922-1933, 1858, 45:152a, 11. 4-5).

Here, the sage uses his senses to guide him to that realm of Emptiness. It seems that his eyes and ears are used not to sense the physical substances around him but to guide him spiritually to another realm. The sage can acquire a vision that allows him to view Emptiness. He is described as being able to "see the changes of the universe ... and observe non-duality ... " (Taisho Shinshu Daizokyo 1922-1933, 1858, 45:152a, 11. 4-5). I suggest that attaining Prajñā, a level of insight into the aforementioned realm, is a spiritual process that moves the sage to a realm beyond the here-and-now. This process of obtaining Prajñā consists of sensation, which generates insight or wisdom regarding the nature of reality. ${ }^{16}$ However, as one learns later in the text, this process is not being "thought" but rather "sensed". The following chapters of Non-complete Emptiness portray a different metaphysical approach:

"These double negations, do they imply that myriad things must be blotted out, that the senses must be prevented from seeing and hearing, that a state must be created which is a soundless, substance-less, void, like a gap in a mountain range, in order to produce the true state?" (Taisho Shinshu Daizokyo 1922-1933, 1858, 45:152b, 11. 1-3).

In the series of rhetorical questions found in chapter two, Seng Zhao rejects the notion that the sage should relinquish engagement with the world and ignore substances and perhaps other entities that trigger the activation of the senses. ${ }^{17}$ The ultimate reality (zhendi 真諦), though empty (kong 空), is not a void ( $x u$ 虛), and it should not be treated as being void of matter. Myriad things, then, should not be avoided by the senses. Thus, as opposed to what was described in the first chapter, here, the senses are thought to be used not for transcending this world but for experiencing it directly. The idea of experiencing reality as a unity (yiqi一氣) in this framework comes from having a tangible, physical experience of connection to myriad things - that is, to mundane reality as one experiences it (Taisho Shinshu Daizokyo 1922-1933, 1858, 45:152a, 1. 3). In this final passage of Non-complete Emptiness, Seng Zhao further strengthens this approach:

"Therefore, a sutra says 'marvelous, world honored one! Unchanging reality is the realm where all dharma are assigned their places'. Not outside of reality are they placed, where they are placed (in the world) that indeed is reality. This being so, is Dao far away? This life of ours is reality. Is the sage far away? Recognize him as in truth he is, and you are the (cosmic) spirit!" (Taisho Shinshu Daizokyo 1922-1933, 1858, 45:153a, 11. 2-5).

The first chapter of Non-complete Emptiness, thus, describes Emptiness as divine, remote or transcendental. Accordingly, the path of the sage is to seek an otherworldly experience of reality. In other parts of the work, however, including in the final passage, Seng Zhao articulates himself differently. Namely, he states that Emptiness is reached in this world as we know it. In those sections, the sage's path is earthly, mundane. The difference between these two dimensions - the transcendental and the mundane-illustrates the relationship between the two truths. As the normative truth is illusory, the transcendental sphere here represents the ultimate truth that is outside the world and is not derived from an ontological existence of objects or beings, such as in the normative reality. However, the experience of the sage within the phenomenal world refutes the transcendental emphasis of the ultimate truth. The dialectic power here is the impermanence of the experience. The fact that Seng Zhao advocates for embracing reality does not mean that he grasps it from a normative permanent viewpoint. I hold that the experience of these seemingly negative spheres described alternately throughout the essay is what allows the two truths to have a dialectical relationship rather than a dichotomy between two philosophical standpoints. 
Each sphere described removes the other of its absolute importance. In this way, the two truths only apply as a description of reality in a framework where they both have a place. These places, however, are not ontological but functional. ${ }^{18}$ Seng Zhao argues through these different dimensions for an Emptiness that resides between those two extremes. While one can easily think that the ultimate reality is positive, a state to aspire to, I believe this is not the case here. There is no ultimate reality that resides outside the illusive phenomenal world. Emptiness cuts through the delusional aspects of mundane reality through the experience of the sage. He finds ultimate reality as his senses provide him with an experience of Emptiness in this world (Taisho Shinshu Daizokyo 1922-1933, 1858, 45:153a, 1l. 2-5).

\subsection{Scholar-Monk}

One can appreciate that inquiry into the role of sensory experiences in what is considered a Buddhist text from this period might sound strange, as we associate Buddhist philosophy with monastic communities and ascetic practice. Moreover, as the term No-self (Sk. anātman, Ch. Wuwo 無我) is traditionally (though not exclusively) related to Emptiness, the use of sensory experiences to demonstrate an entity seems rather questionable. I propose, nevertheless, a sensory framework to account for the construction of a certain identity for the sage described in the text. Seng Zhao did not have to expound on Emptiness through a relation to a concrete being. For example, if he had leaned strictly on the writing style of the Laozi, he might have initiated a more abstract discussion. Nonetheless, he described a sage (shangren 聖人). The fact that a sage, a being, was chosen to describe Emptiness does not necessarily imply that Seng Zhao affirmed the existence of a continual self. This would mean that he renounced impermanence (Sk. anitya, Ch. Wuchang 無常), a conceptual cornerstone of Buddhism.

The sage functions as a rhetoric tool, a Skillful Means (as discussed above) through which Seng Zhao communicates his message, attempting to guide his readers in the path to liberation. The figure of the sage, as used in the explanation of Emptiness, holds tension that exists in life, outside the philosophical storyline of the essay. Outside the essay, there is an author, and his experience and situation can affect how we perceive Non-complete Emptiness. Therefore, an additional point that is relevant for the discussion at hand is the social phenomena of the "scholar-monk" status. A significant part of the large textual corpus of Buddhist writings from the studied period on matters of ethics, metaphysics, rituals, and history was written by monks.

Before the arrival of Buddhism to China, ideal scholars were mostly divided into two types: the worldly, or classic, scholar, who engaged in matters of government, state, and rituals; and the hermit, who removed himself from society, rejecting conventional rites and norms and public affairs. The latter devoted himself to private study and self-cultivation practices (Liebenthal 1968, p. 98). I see a degree of this latter scholastic ideal in the second chapter of the Zhuangzi, where Zhuangzi refuses the officers from the Chu state who come by the king's order to offer him a ruling position. In his response, he tells a story of a dead turtle kept in cloth for 3000 years and announces that he prefers to be "a live turtle in the mud" (Zhuangzi 2000, p. 47, 11. 1-4). In his refusal, Zhuangzi embodies the second type of scholar, which holds, in my opinion, a degree of asceticism, whereas the first type of scholar could be described as "a dead turtle with his bones sacredly kept" (Zhuangzi 2000, p. $47,1.3)$. I hold that Seng Zhao was neither of these two types, but rather, was a dialectic manifestation of both. The scholar-monk's mission demanded that he be proficient in both the Buddhist scriptures and the Chinese classics, as is very much apparent in Seng Zhao's writings. In that sense, Seng Zhao, as with his sage, is "neither this or that". He is not outside of concrete social reality and not inside it.

According to John Kischnick, the scholar-monks had to be well versed in the classics, even if just to "lament their limitations" (Kieschnick 1997, p. 113). In other words, to demonstrate their respect for Buddhist knowledge, they had to know the Chinese classics thoroughly, and from that familiarity, acknowledge their shortcomings. Seng Zhao's 
biography states that he was introduced to the Vimalakirti sutra and now has something to rely on (Yifa 2009, pp. 5-7). Buddhism might have offered Seng Zhao something that his deep love for the Chinese classics did not-namely, practice. The religion arrived in China and, with it, provided a detailed set of rules. Throughout the fourth and fifth centuries, the monastic code (Sk. Vinaya Ch. Jielu 戒律) was translated to Chinese and partial versions of it were practiced beforehand (Zürcher 1972, p. 81).

The monastic code was an elaborated set of rules that generally guided monks in their daily lives and behavior toward a life of retreat and abstention. By that time, Buddhist monks already differentiated themselves from lay people, left their homes to be ordained in a monastery (chujia 出家), and therefore gave up many mundane, sensory, and physical habits of everyday life (Yifa 2009, p. 4). I turn to ask here whether Seng Zhao's philosophical ideas, the prescriptions to which the text implies, all point to a rigid ascetic message that his social identity represents. The monk Seng Zhao obviously conducts himself with a degree of asceticism. I have shown that, on the one hand, Seng Zhao sends an earthly, mundane message of a being guided through its senses. Thus, while Seng Zhao was dedicated to the Buddhist translation process and his Buddhist cultivation, as I have shown above, these elements were aligned with the Daoist idea of the wise men, who do not engage in leadership of the state or linguistic explanations of the world but rather undergo selfcultivation (as with the turtle in the mud). Furthermore, I hold that it is important not to rule out the influence of Confucian thought on the writing of the Seng Zhao's entity. Given that Seng Zhao had mastered the Confucian classics, the figure of the sage in Non-complete Emptiness might have also been influenced by the Confucian idea of "sagehood" (junzi 君子), which is a more concrete, social, and moral term that is at the center of Confucian philosophy. The relationship between Confucianism and Buddhism is not a cut-and-dry dichotomy. It is not only concerned with the interaction between two different traditions but also with the mutual transformation between indigenous and foreign cultures. In the first stage of its introduction into China, Buddhism was interpreted and understood mainly through Daoism and Confucianism. The Buddha was seen as a similar figure to a Daoist deity or a Confucian sage. When more accurate translations of the Buddhist texts were available, people became aware of the differences and contradictions between Buddhist doctrines and the teachings of Confucius and Laozi (Yao 2000, p. 231). Therefore, Seng Zhao's sage can also reflect the grounded, earthly nature of a Confucian sage.

There is, as I have discussed here, a dialectic relationship of harmony in Seng Zhao's writing influences from Chinese traditions of thought to Buddhist philosophy. Consequently, this relationship transcends the idiosyncratic nature of Seng Zhao as an author and self-cultivator. I contend that this dialectic relationship continues further to the relationship between Seng Zhao's monastic identity and the identity of the sage he conveys, an entity guided by senses. Therefore, while his own path is monastic, he could suggest a different path for liberation for his readers, which is nonetheless in accordance with his own particular eclectic identity. This resonates the apparent duality between Non-complete Emptiness and his ascetic lifestyle.

\subsection{The Sage and the Senses}

I wish to discuss the relationship between the sage and the senses further. In order to do this, I turn to the text traditionally considered the source of Seng Zhao's thought (Liebenthal 1968, p. 24). In the MMK, Nāgārjuna examines the senses, primarily sight. He shows that vision is relational and is not an intrinsically identifiable phenomenon.

"Seeing, hearing, smelling, tasting, touching, and mind are the six sense faculties. Their spheres are the visible objects ... " (Liebenthal 1968, p. 137).

The senses are dependent on each other and on objects (Garfeild 1995, p. 138). As Seng Zhao tells the sage's story, he does not explicitly describe the senses. It is not clear whether, as with Nāgārjuna, he holds that the sense organs stand on their own, apart from the "myriad things" - the objects (wanwu 萬物). However, what activates the senses are the objects, and so although not described specifically, this description of the senses 
is not far from Nāgārjuna's approach. I wish to suggest that the revealed structure of identity is a form of "open entity" that is built on sensory experiences. These experiences are constructed over and over again in reaction to the objects, and they form the entitythe sage. This entity is therefore not permanent but also not non-existent. The formed entity can be considered open. The senses and the surroundings of the myriad things are unified through experience. When acting together as an entity, they are defined through the relationships between senses and objects. This "open entity" is juxtaposed with an entity or being with distinct and independent existence. It is then not fixed but open, porous.

In comparing Seng Zhao's approach to that of Nāgārjuna, I have, so far, considered the physical senses. As seen in the MMK quote above, Buddhism traditionally considers the mind to be the sixth sense. Therefore, the next inquiry regarding this entity is that of mind, awareness, and cognition. Does this loose entity have cognition and awareness of itself or of the world around it? Later-developed schools, such as the Yogācāra School, criticized Madhyamaka's view of Śunyatā. Madhyamaka holds that all things are empty and devoid of a definite nature. As such, any speculation about the true nature of things is erroneous. The Yogācāra School, by contrast, holds that while things are illusory, there is still a conscious entity. Every object, whether mental or not mental, may logically or dialectically be proven illusory. However, in order to be illusory, there must be a certain thought that suffers from illusion (Cheng 1991, p. 25). Scholars have long debated Seng Zhao's grasp of Indian Madhyamaka and whether or not his philosophy faithfully represents its doctrine of Śūnyatā (Dippmann 1997, pp. 2-7). ${ }^{19}$

In my reading of the text, I intentionally do not classify Non-complete Emptiness as Chinese Madhyamaka, Daoism, or anything else in particular, although I do acknowledge that these traditions had significant impacts on Seng Zhao's writings. Nevertheless, with respect to consciousness of mind as an indispensable characteristic of entities, it is possible that Seng Zhao did not fully align with either the Yogācāra or the Madhyamaka streams. For Patt-Shamir, this opening sentence of the text denotes the absence of an anthological dimension in human understanding: "a perfect void where nothing grows and decays" (Patt-Shamir 2011, p. 476). In this framework, she explains Seng Zhao's use of Prajñā in the phrase that follows it, "the transcendent realm as it shows in the dark mirror of Prajñā", as the only reference to cognition (Taisho Shinshu Daizokyo 1922-1933, 1858, 45:152a, 1. 2). Prajñā, I suggest, ought to be understood as a deep insight that can be reached from the connection between Seng Zhao's "entity in process" to all objects around him. Hence, Prajñā is assigned to that entity and offers it a correct view on reality, which can appear as cognitive acuity and, through that, resembles the Yogācāra view of an entity, which is conscious. However, while Seng Zhao himself used Madhyamaka dialectic tools such as the two truths, his described entity does not categorially or logically analyze reality in order to understand Emptiness (Taisho Shinshu Daizokyo 1922-1933, 1858, 45:152a, 1. 2). Instead, it reaches it through a sensory experience.

The "open entity", as described above, accounts not only for the philosophical tension concerning the sage in Non-complete Emptiness, but also the tension between his rhetorical tools and the message he conveys to the reader. While Seng Zhao, the scholar, might be a conscious entity who engages in methodological cognitive acuity for the descriptive part of the essay, his prescriptive message to the reader is to self-cultivate through direct engagement with objects. If the entity holds a certain level of awareness, it seems that it is turned outwards to all objects around him, through sensation, and not inwards to a logical enquiry regarding his own ontological existence. Prajña, in this sense, is gained from the experience or the practical path, and it can be described as more of a bodily acuity-though not necessarily of a cognitive nature. One can think of the example of plants, which have sense organs but no cognition. Plants can, therefore, through sensations, make different connections among themselves and their surroundings. ${ }^{20}$ I suggest that this "knowing" (shen 審) of Non-duality (shen yiqi yi guanhua 審一氣以觀化) (Taisho Shinshu Daizokyo 1922-1933, 1858, 45:152a, 1. 3) involves the identification of this entity with the myriad things-among them, rocks, plants, and animals. Given the connection of Seng Zhao with 
Laozhuang literature, a non-human (centric) approach to his writings can be considered, an approach that is increasingly being applied to Daoist texts. ${ }^{21}$ One example of this approach appears in the Zhuangzi, when the Daoist sage and everything in the world are made of the same basic energy (yiqi一氣) (Zhuangzi 2000, p. 60, 11. 17-18). The approach to the sage and nature in both the Zhuangzi and Non-complete Emptiness ascribes particular importance to human beings and their differentiation from the rest of the natural and phenomenal world.

\subsection{Sensory Experiences and Asceticism}

The following passage is taken from chapter three in the Zhuangzi and mentions the senses:

"After three years, I ceased to see it as a whole. Now I deal with it in a spirit-like manner and do not look at it with my eyes. The use of my senses is discarded, and my spirit acts as it wills. Observing the natural lines, (my knife) slips through the great crevices and slides through the great cavities" (Zhuangzi 2000, p. 8, 11. 4-6).

This passage depicts a cook cutting up an ox. After years of training, the skilled cook no longer uses his sight to see the ox. He neglects his senses and, instead, follows his spirit (shen 神). According to Liebenthal, this passage of the Zhuangzi inspired Seng Zhao's description of the sage (Liebenthal 1968, pp. 18-20). Nevertheless, there is a surprising difference between the texts when it comes to the senses. The Zhuangzi calls for a spiritual experience, in which one leaves aside the sense organ and follows something else-something heavenly and divine. ${ }^{22}$ Seng Zhao, for his part, suggests following the senses in order to experience the world-or the transcendent realm (in chapter one) through the senses. As I suggested above, the senses are what build the experience and the entity; hence, they cannot be abandoned. Zhuangzi advises putting aside the sensory experience and connecting to something beyond this. ${ }^{23}$ The aforementioned story in the Zhuangzi might convey a more ascetic message than that portrayed by Seng Zhao. The former calls for intense practice and training, which leads one to relinquish the senses and walk through the empty cracks of this world without acknowledging the world (Zhuangzi 2000, p. 8, 1. 4). There is a similar message of abstinence, of abandoning the senses, in the Laozi. For example:

"The five colors cause blindness to a man's eyes;

the five sounds cause deafness to his ears;

the five tastes injure his palate;

riding and hunting makes his mind go wild with excitement..." (Laozi 2000, p. 45,

11. 10-25).

While LaoZhuang literature can be read as a strong ascetic approach, (Eskildsen 1998, p. 2). here, Seng Zhao the monk recommends that one experiences the world through the senses, perceiving its substance, colors, and sounds (Taisho Shinshu Daizokyo 1922-1933, 1858, 45:152a, 11. 11-12). With respect to its approach to the senses, one can say that the Zhuangzi's cook is more devoted to his spiritual path than Seng Zhao the monk. The parable of the cook can thus stand for transcendence to the spiritual liberation of an enlightened being. Accordingly, the master uses the senses until there is no longer a need for themuntil he reaches a state of complete liberation. However, Zhuangzi has a spiritual path, but the path leads the cook straight back to the world, with no mentioning of another realm he aspires to reach - as with the enlightenment notion in Buddhist texts.

Conversely, it can be argued that Seng Zhao represents a Bodhisattva ideal of "sagehood" on earth. Not only does the Bodhisattva ideal explain the mundane aspect of Emptiness without transcendence, it can also account for the adherent use of the senses and a more nuanced ideal of asceticism. Rolf Stein holds that the concept of "pivoting" or "overturning" (Sk. paravrtti Ch. suozhuan 所轉) seems to lie behind the view that rather than negating passion, desire, and sexuality, one can transmute them. This allows the Bodhisattva in different Buddhist scriptures to indulge in physical enjoinments without 
being defiled by them (Stein 1974, pp. 499-517). On a more general note, Mahayana Buddhism argues that the ultimate truth can be discovered by those who are aware of the reality of desire and can transmute it (Faure 1998, p. 4). However, while these notions of the Bodhisattva can supply a Buddhist doctrinal explanation for the sensory aspect of the entity, one has to remember that Seng Zhao himself was a monk who chose an ascetic life.

However, the issue of homogeneity with respect to asceticism in a monastic order, should be mentioned here. In The Eminent Monk, John Kischnick analyses monks' biographies and shows different levels of rigor concerning food and alcohol consumption, sexual relations, and dress code. He argues that while the rules about these behaviors were considered basic, there was still room for individual interpretation and self-expression in all fields. Furthermore, while these practices seemed clearly ascetic to the outside observer, inside the monastic Buddhist world, the situation was more complex. Throughout Chinese history, Kischnick claims, monks have decried a deterioration in obedience to the vinaya rules in monastic orders, with every generation questioning an ancient Indian ideal of monasticism that never existed (Kieschnick 1997, p. 33). In his view, the lamentations of the monks in the biographies ought to be read with a critical eye. Records of relative individualism when it comes to different practices, as well as the breaking of prohibited practices, such as sexual contact within the monastic community, consumption of meat, and so on, exemplifies the idea that the use of senses, or, more precisely, monks' abstinence from things that activate the senses, was indeed an issue that produced a spectrum of tensions within society. Nevertheless, these tensions do not necessarily point to a split concept of monkhood. The survival of the monastic ideal to this day shows, to an extent, that in spite of these tensions, there is a balance of practice that holds this section of the religious society. Therefore, when juxtaposing the idealized image of purity associated with monkhood with the reality of monastic historical accounts, we return again to a dialectic harmony that is beyond dichotomic definitions. This is not to say that Seng Zhao himself was violating monastic codes, but only to suggest that his social sphere also provoked a spectrum of ideas about asceticism. Moreover, in its most basic sense, the Middle Way (Madhyamaka), if translated to a view on asceticism, can offer a path to liberation which sets the practitioner on a scale somewhere between complete sensory indulgence and absolute abstention.

\section{Conclusions-The Dynamics of Splitting}

In this article, I have presented primary notions, historical outlines, and trajectories that I believe are important to our learning of Seng Zhao's understanding of Emptiness. The richness of the materials used by Seng Zhao is phenomenal, which encourages us, his readers, to make choices. My methodological choices in this article were motivated by gaps and unsolved questions and tensions. These are, in my opinion, the key parts of Non-complete Emptiness. An essential tool employed throughout this article was finding the third corner to the negations that create tension. This work finally led me to the dialectic relation between the earthly and transcendental views of Emptiness present in Seng Zhao's philosophy as well as the dialectics between the call for a mundane use of the senses and a thrust for asceticism. Furthermore, I explored the connections of these aspects to Seng Zhao's life-course and identity as a scholar-monk. This complex picture of incoherencies and relationships can represent a set of tensions, though I believe these are not historically or logically problematic. On the contrary, in my view, they illustrate the diversity in the religious and philosophical environments of that period.

As mentioned above, Patt-Shamir argued that Seng Zhao's philosophy of Emptiness has a kind of "dual citizenship". In her view, his treatise can be understood from both Buddhist and Daoist points of view (Patt-Shamir 2011, p. 475). I embrace this approach, for I, too, put little stock into questions over Seng Zhao's understanding of Indian Madhyamaka or whether his philosophy is a "Sinification" of Buddhism or, conversely, a "Buddhization" of Chinese philosophies. As I see it, although the text holds great importance for different Buddhist traditions throughout East Asia, it can also be considered influential for Daoist or Confucian studies (Dippmann 1997, p. 31). Furthermore, in seeking to identify an entity, a 
scholar, or a text within a jungle of traditions, we might benefit from looking at dialectic pairs, such as those laid out in this paper, instead of following a prescribed narrative accepted within one tradition. Within each philosophical or religious "citizenship", one, indeed, finds a multiplicity of religious, social, and philosophical identities. This dynamic of splitting each "citizenship" into multiple pairs might not facilitate a nominal identification of religious or philosophical phenomena, but it can help us to observe them more closely.

Funding: This research received no external funding.

Conflicts of Interest: The authors declare no conflict of interest.

\section{Notes}

1 I owe a great debt of gratitude to Galia Patt-Shamir, who introduced me to this text, and for her careful guidance in reading and working on this research in earlier stages. I also express my deep gratitude to Teng Weijen 鄧偉仁 for insightful comments and suggestions on this manuscript in an earlier version of it presented in the conference "From the Ground Up: Buddhism and East Asian Religions" in the University of British Colombia 2018.

2 See the works of: (Jiang 1990, 2010; Chen 1999, 2004; Fang 2016; Tan 2008; Liebenthal 1968; Robinson 1976; Dippmann 1997).

3 Kumārajīva, (Ch. Jiumoluoshi 鳩摩羅什), the renounced middle Asian translator who hailed from the ancient kingdom Kucha, was summoned by the eastern Jin king to be a Head priest and then settled in Chang'an. To this day, the translations initiated by Kumārajīva's team are used by religious practitioners and researchers alike. By the time of Seng Zhao's arrival to Chang'an, Dao'an and Fo'nuan had already laid the foundations for him: Chang'an was already an important center for translation and Buddhist textual activity. See also (Jiang 2010).

$4 \quad$ For the purpose of clarity, throughout this article, I will use the English translation of this term.

5 In the Madhyamaka school of Mahāyāna Buddhist Philosophy, the Middle Way (Sk. Madhyamaka) refers to insight into Emptiness. For more on the Middle Way, see (Garfeild 1995; Siderits and Katsura 2013; Westerhoff 2009).

6 See also: (Liebenthal 1968; Patt-Shamir 2011).

7 Ichimura's hypothesis is that Seng Zhao had been exposed to the writings of the Neo-Mohists, which used the ancient logical system. One example that he cites as evidence for this is Seng Zhao's use of "xiao" (效), which, in the Mohist tradition, means "standard mode of thought". Xiao, in short, is a universal system of causality; its meaning is well-established through induction. It is a paradoxical method of inference, which is compared to the Sanskrit principle of inference ridictio-ad-absurdum (anvaya-vyatireka). (Ichimura 1992, pp. 52-56).

The Dao literally translates to "way", "road" or "path" and is a fundumental concept in various philosophical traditions in China. It is a concept that has been used in many Confucian and Daoist texts since the Chinese formative era of classical thought from the time of the Zhou dynasty (1046-256 BC) until the present day. See (Chan 1969).

9 For Dao see comment 8. In Dharma I refer here to the teachings of the Buddha.

10 This article focuses on the Buddhist Confucians and Daoist influences of the text. There is a rich and diverse religious and spiritual environment present in China. In terms of traditional social and religious life in China, there seems to be a recognised division of labor between the three doctrines. Confucianism was expected to provide the moral principles for social and political life, while Daoism and Buddhism were developed to sanction Confucian morality and deal with psychological and spiritual issues. This labor division played a key role in maintaining the balance between them and contributed to the co-existence and mutual acceptance that exists in all three doctrines. For more information on religious hybridity in China, see (Yao 2000; Yao and Zhao 2010; Oostveen 2019; Goossaert 2005; Mollier 2009).

11 In this period, Buddhism flourished in China alongside other movements considered to be neo-Daoist. Two of these were "study of the dark" (xuanxue 玄学) and "pure talk" (qingtan 清谈), which arose from Wangbi's annotations to the Laozi and the Book of Changes (Yijing 易經) as well as from Guo Xiang's annotations to the Zhuangzi. These two movements provoked discussions of Daoist and Buddhist ideas without clearly distinguishing between them. This phenomenon is referred to by east Asian scholars as “Ge-yi Buddhism” (格义佛学).

12 See my suggestion of an"open entity" in page 10-11.

13 See (Liebenthal 1968; Robinson 1958; Cheng 1991).

14 For further discussion about mysticism, see these outstanding works: (James 2002; Forman 1990; Katz 1978; Stace 1961). For discussion about mysticism in China, see (Ching 1997; Roth 1999).

15 See also (Liu 1987).

16 See the discussion of Zyporyn on Prajñā: (Zyporyn 2019).

17 I lean on the division of the chapters as found in Liebenthal's and Robinson's translations.

18 Seng Zhao stresses that he used rhetoric tools due to lacking another option. He holds that language creates a dual notion regarding reality. He, nevertheless, chose to express his ideas through it. 
See also (Robinson 1976; Liebenthal 1968).

See (Trewavas 2005; Karban 2015).

The scope of this paper is not broad enough for a full discussion of LaoZhuang philosophy and the N Post Humman. For further reading, see (Wenning 2014; Nelson 2014; Dickman 2019).

See more in (Ames 1998).

I wish to point out that there are various metaphysical messages in the different chapters of the Zhuang Zi. Among them is one that speaks for completely opposite and mundane earthly interpretations of Dao. Here, I use the ascetic message found in this chapter, with no claim that it is an exclusive concept of the Zhuang $\mathrm{Zi}$ as a whole.

\section{References}

Ames, Roger T. 1998. Wandering at Ease in the Zhuangzi. SUNY Series in Chinese Philosophy and Culture; Ithaca: State University of New York Press.

Chan, Wing-tsit. 1969. A Source Book in Chinese Philosophy. Princeton: Princeton University Press.

Chen, Jian . 2004. Sengzhao de bu zhenkong yi jiantan liujia qizong dui kong de lijie 僧肇的“不真空”义兼谈“六家七宗”对“空”的理解 [Seng Zhao's Interpretation of Sūnyatǎ]. 山东大学学报 6: 58-63.

Chen, Shefu 沈顺福. 1999. Sengzhao zhixue yu xuanlao sixiang bijiao yanjiu 僧肇哲学与玄老思想比较研究. [A Comparative Study on the Philosophy of Teng Zhao and the Xuanlao thought]. 东岳论丛 20: 100-6.

Cheng, Xueli. 1991. Empty Logic. Delhi: Molital Banarsidass.

Ching, Julia. 1997. Mysticism and Kingship in China. Cambridge: Cambridge University Press.

Dickman, Eric Nathan. 2019. A Zhuangzian Tangle: Corroborating (orientalism In?) Posthumanist Approaches to Subjectivities and Flourishings. Religions 10: 382. [CrossRef]

Dippmann, Jeffery W. 1997. The Emptying of Emptiness. Ph.D. dissertation, Northwestern University, Evanston, IL, USA.

Eskildsen, Stephan. 1998. Asceticism in Early Taoist Religion. Albany: State University of New York Press.

Fang, Tingling 方映灵. 2016. Foxuan zhijian cong bu Zhenyong lun xi sengzhao foxue xuanxuehua wenti 佛玄之间: 从《不真空论》 析僧肇佛学玄学化问题 [Between Buddhism and Metaphysics: Analyzing the Metaphysics of Monk Zhao's Buddhism from Non-Complete Emptiness]. 现代哲学 146: 120-26.

Faure, Bernard. 1998. The Red Thread: Buddhist Approaches to Sexuality. Princeton: Princeton University Press.

Forman, Robert K. C., ed. 1990. The Problem of Pure Consciousness. New York: Oxford University Press.

Garfeild, Jay. L. 1995. The Fundamental Wisdom of the Middle Way- Ngarjuna's Mulamadhyamakakarika. New York: Oxford University Press.

Goossaert, Vincent. 2005. The Concept of Religion in China and the West. Diogenes 52: 13-20. [CrossRef]

Ichimura, Shoshei. 1992. On The Paradoxical Method Of The Chinese Madhyamika: Seng-Chao And The Chao-Lun Treatise. Journal of Chinese Philosophy 1: 51-71. [CrossRef]

James, William. 2002. The Varieties of Religious Experience. A Study in Human Nature. London and New York: Routledge.

Jiang, Shuzhuo 蒋述桌. 1990. shi lun fojiao meixue sixiang 试论佛教美学思想 [On Buddhist Aesthetics]. 云南社会科学 2: 76-83.

Jiang, Yuzhi 蒋玉智. 2010. xi sengzhao dui foxue kong guan de lun zhenfu bu zhenkong lun jin fan 析僧肇对佛学“空”观的论证附: 《不 真空论》今译. [On Seng Zhao's Demonstration of “Empty”]. 同济大学学报(社会科学版) 21: 66-72.

Kantor, Hans-Rudolf. 2010. 'Right Words Are Like the Reverse'-The Daoist Rhetoric and the Linguistic Strategy in Early Chinese Buddhism. Asian Philosophy 3: 283-307. [CrossRef]

Karban, Richard. 2015. Plant Sensing and Communication. Chicago and London: University of Chicago Press.

Katz, Steven, ed. 1978. Mysticism and Philosophical Analysis. Oxford and New York: Oxford University Press.

Kieschnick, John. 1997. The Eminent Monk: Buddhist Ideals in Medieval Chinese Hagiography. Studies in East Asian Buddhism. Honolulu: University of Hawaii Press.

Laozi 老子. 2000. A Concordance to the Laozi 老子逐字索引. ICS Series. Edited by Din Cheuk Lau. Hong Kong: Commercial Press.

Liebenthal, Walter. 1968. Zhao Lun: The Treatise of Seng Zhao. Hong Kong: Hong-Kong University Press.

Liu, Ming-Wood. 1987. Seng Zhao and The Madhyamaka Way of Refutation. Journal Of Chinese Philosophy 14: 97-109.

Mair, Victor, and Tansen Sen. 2012. What Is Ge-yi Afetr All? China Report 48: 29-59. [CrossRef]

Mollier, Christine. 2009. Buddhism and Taoism Face to Face: Scripture, Ritual, and Iconographic Exchange in Medieval China. Honolulu: University of Hawai'i Press.

Nelson, Eric S. 2014. The Human and the Inhuman: Ethics and Religion in the Zhuangzi. Journal of Chinese Philosophy 41: 723-39. [CrossRef]

Oostveen, Daan F. 2019. Religious Belonging in the East Asian Context: An Exploration of Rhizomatic Belonging. Religions 10: 182. [CrossRef]

Patt-Shamir, G. 2011. The 'Dual citizenship' of Emptiness: A reading of the Bu Zhenkonglun. Journal of Chinese Philosophy 3: 474-90. [CrossRef]

Robinson, Richard. H. 1958. Mysticism and Logic in Seng-Chao's Thought. Philosophy East and West 8: 99-120. [CrossRef]

Robinson, Richard. H. 1976. Early Madhyamika In India and China. Delhi: Motilal Banarasidass. 
Roth, Harold D. 1999. The Laozi in the Context of Early Daoist Mystical Praxis. In Religious Philosophical Aspects of the Laozi. Edited by Mark Csikszementmihalyi and Philip J. Ivanhoe. New York: SUNY Press, pp. 59-126.

Siderits, Mark, and Shoryu Katsura. 2013. Nagarjuna's Middle Way: Mulamadhyamakakarika. Somerville: Simon and Schuster. Stace, William T. 1961. Misticism and Philosophy. London: Macmillan \& Co.

Stein, Rolf Alfred. 1974. Etude du Monde Chinois: Institutions et Concepts. Paris: Annuaire du Collège de France.

Taisho Shinshu Daizokyo 大正新修大藏經. 1922-1933. The Taisho Tripitaka in Chinese. Tokyo: Taisho Issaikyo Kakokai 大正新修大藏經 刊行會.

Tan, Mingran. 2008. Emptiness, Being and Non-being: Sengzhao's Reinterpretation of the Laozi and Zhuangzi in a Buddhist Context. Dao 7: 195-209.

Trewavas, Anthony. 2005. Green Plants as Intelligent Organisms. Trends in Plant Science 10: 413-19. [CrossRef] [PubMed]

Waley, Arthur. 1958. The Way and its Power: A Study of the Dao De Jing in China and Its Place in Chinese Thught. New York: Grove Press.

Wenning, Mario. 2014. Heidegger and Zhuangzi on the nonhuman: Towards a transcultural critique of (post)humanism. In Asian Perspectives on Animal Ethics in: Rethinking the Nonhuman. Edited by Neil Dalal and Chloë Taylor. London: Routlege.

Westerhoff, Jan. 2009. Nagarjuna's Madhyamaka: A Philosophical Introduction. Oxford: Oxford University Press.

Yao, Xinzhong, and Yanxia Zhao. 2010. Chinese Religion: A Contextual Approach. London and New York: Continuum.

Yao, Xinzhong. 2000. An Introduction to Confucianism. Cambridge: Cambridge University Press.

Yifa. 2009. The Origins of Buddhist Monastic Codes in China: An Annotated Translation and Study of the Chanyuan Qinggui. Honolulu: University of Hawaii Press.

Zhuangzi 莊子. 2000. A Concordance to the Zhuangzi 莊子逐字索引. ICS Series. Edited by Din Cheuk Lau. Hong Kong: Commercial Press.

Zürcher, Eric. 1972. The Buddhist Conquest of China: The Spread and Adaptation of Buddhism in Early Medieval China. Leiden: Brill.

Zyporyn, Brook. 2019. Seng Zhao's "Prajñā is Without Knowledge": Collapsing the Two Truths from Critique to Affirmation. Journal of Indian Philosophy 47: 831-49. [CrossRef] 